\title{
Corporate representations of the child worker: Swedish company websites offering sales opportunities to schoolchildren
}

J ohanna Sjöberg and Nigel Smith-MacGowan

The self-archived postprint version of this journal article is available at Linköping University Institutional Repository (DiVA):

http:// urn.kb.se/ resolve?urn=urn:nbn:se:liu:diva-147524

N.B.: When citing this work, cite the original publication.

This is an electronic version of an article published in:

Sjöberg, J., Smith-MaoGowan, N., (2017), Corporate representations of the child worker: Swedish company websites offering sales opportunities to schoolchildren, J ournal of Children and Media, 11(4), 451-465. https:/ / doi.org/ 10.1080/ 17482798.2017.1352527

Original publication available at:

https:// doi.org/ 10.1080/17482798.2017.1352527

Copyright: Taylor \& Francis (Routledge) (SSH Titles)

http:// www.routledge.com/ 


\title{
Corporate representations of the child worker: Swedish company websites offering sales opportunities to schoolchildren
}

\author{
Authors: Johanna Sjöberg \& Nigel Smith-MacGowan \\ Author contact details, corresponding author: \\ Johanna Sjöberg \\ Department of Thematic Studies - Child studies, Linköping University, Linköping, Sweden. \\ johanna.sjoberg@liu.se \\ +4613282075
}

\begin{abstract}
This study explores how companies specialized in a schoolchild work force position children's work and the working child at their official websites. The material is four websites from Swedish companies explicitly offering schoolchildren under 13 opportunities to sell products on commission in order to raise money for school trips. The study demonstrates complexity and contradictions in the companies' communication of the child worker.
\end{abstract}

Keywords: visual discourses, websites, children's work, middle school, on-line marketing, visual analysis, child labour, child employment

\section{Introduction}

This study aims to explore how companies specialized in a schoolchild workforce mediate children's work and the working child. The scrutinized material is four official Swedish language websites from companies explicitly offering schoolchildren under 13 years of age opportunities to raise money for school trips through commission-based sales. 
The background for the study is that since the mid-1900s work in the western world has been considered appropriate for adults but not for children (Lee, 2001). Nevertheless, children in affluent countries do work. In Sweden, for example, children sell commodities to a value of several million euros every year. Indeed, there is a line of business specialising in school children working as sales persons. These are companies offering sales opportunities, for example of biscuits, toffees, candles and socks on commission, often in order to raise money for school trips (Engwall, Sjöberg and Söderlind, 2008; Samuelsson, 2008; Tonström, 2010). The existence of for-profit companies specialised in a schoolchild workforce exposes children's labour as essential in some lines of business. Although it is outside the labour market and outside of traditional work places, it confirms that children in contemporary Sweden are undertaking work that is significant.

Children under the age of 13 may conduct light and safe work as long as it does not impinge on their health, development or schooling (SFS 1977:1160 §2). Yet, there is an erroneous belief in Swedish society that it is illegal for children to work (Samuelsson, 2008). The misconception is connected to the perception, held by both adults and children, that children in Sweden do not undertake real work - that they actually do not work. Instead their work-related undertakings are seen as merely fun and educational, as an investment for the future and a preparation for adulthood (Samuelsson, 2008). Studies from New Zealand (Gasson, Calder, Diorio, Smith \& Stigter, 2015) and Northern Ireland (Leonard, 2003) indicate this focus on future implications of children's work is not unique for Sweden.

Swedish companies using commission-based child salespersons do not publicly account for how many hours children work for them or how much children are paid for their commission sales (Engwall et al., 2008). It is however clear that the companies make considerable profits using this business model (Lindahl, 2016; Tonström, 2010; Nöjd, 2008). But rather than being explicit regarding their dependency upon a child workforce these companies, according to a 
minor study on the subject, give verbal prominence to their "helping" school classes to finance school trips (Engwall et al., 2008). Thereby the companies appear as first and foremost working for children and not the other way around.

Given this background it is highly interesting to further investigate how companies that use children as a workforce represent children's work and how they describe the offered sales work. Questions posed by the study are: How do companies argue that schoolchildren should conduct sales work for them and what discourses of children and work do they produce and reproduce?

\section{Representing the working child}

The academic field of children's work in affluent societies primarily explores and problematizes what work children perform in their daily life (see Howieson, McKechnie \& Semple, 2012; Bourdillon, Levison, Myers \&White, 2010; McKechnie et al., 2009; Engwall \& Söderlind, 2009). Often it is done in line with the new sociology of childhood (Prout \& James 1997) where children's own voices are central (e.g. Samuelsson, 2008; Hobbs, Stack, McKechnie \& Smillie, 2007; Leonard, 2003). This study, instead of being interested in real children's undertakings, focuses on corporate communications and mediated notions of children's work. From a different angle it thereby contributes knowledge to the academic field of children's work, but first and foremost it contributes to the field of mediated representations of children and to children and advertising.

Representations of children in visual media have been studied in depth by several international scholars (f.ex. Higonnet, 1998; Cross, 2004; Holland, 2004; Gennaro, 2010; Kaziaj, 2016). Significant focus in this field is on issues regarding childhood innocence and sexuality. Other examples of topics dealt with are representations of children's rights in NGO campaigns (Wells, 2008) and representations of foster care in news media (Riggs et al 2009). 
Children and work is not a previously discussed topic. Phil Mizen (2005) however analyses children's work from a visual point of view. His material is photographs taken by working children themselves, revealing children's "light work" in affluent societies as both mundane and repetitive.

\section{Raising money for school trips}

Much of the sales work that children in Sweden conduct is done in relation to school, in order to fund school trips. The reason as to why children fund their own school trips in this way is that Swedish compulsory schooling is legally prescribed to be free of charge, allowing parents to only occasionally and voluntarily contribute small amounts of money (SFS 2010:800, 10§10, 11). These minor contributions are generally insufficient to cover the cost of a school trip.

The tradition of school trips in Sweden developed at the turn of the twentieth century with the objective being for children to learn and experience their homeland (Rantatalo, 2002). Today at least one out-of-town school trip is a somewhat mandatory part of the school experience, connected to a norm of an ideal happy childhood (cf. Aretun, 2007; Kverndokk, 2007; Markovich, 2016). School trips often occur at the end of middle school, when the children are 12-13 years old. Depending on the conditions of the planned trip the raising of funds, and accordingly the sales work, begins years prior. The work is carried out during children's spare time but is sanctioned by teachers in return for a trip with more or less educational purposes. The trip is scheduled to occur fully or in part during school time. The work thus conjoins school and private life.

Svein Larsen and Dag Jenssen (2004) show that children appreciate school trips for the joy of being together. Anticipating a fun trip is thus something that might function as an encouraging motive to get the work done when raising money for the school trip. For although children consider work done together with others as a pay off with a positive group feeling and 
friendship (Samuelsson, 2008), funding a school trip demands hard work on the part of the individual child. In a study of Norweigan school trips Kverndokk (2007) quotes a girl arguing that her upcoming school trip to Poland, which will include an emotionally strenuous visit to a concentration camp, is going to be a final treat for the exhausting sales work she and her classmates had performed. The quote reveals the importance of realising the school trip, no matter the costs.

\section{Corporate communications with children}

Companies trying to recruit child workers for the raising of funds for school trips, present their objectives on websites sharing features with job advertisements. Hereby their websites differ from most corporate communication aimed at Swedish children; that is of marketing trying to make them interested in a commodity, a brand or a commercial concept to consume (Sjöberg 2013).

Marketing trying to recruit children as a workforce is sparsely studied and little is known of how children's work tends to be commercially represented in Sweden or elsewhere. Kristina Engwall et al. (2008) who touches upon the subject, shows it was common for Swedish companies to advertise for child labour during the first half of the twentieth century. The jobs offered then were agricultural, industrial and in the service industry. Similar to the companies discussed here, some recruited children to sell goods on commission but the jobs were primarily in the formal labour market, and none of the companies seem to have sought engagement of whole school classes.

\section{Theory and method}

Important theoretical inspiration for this study is Anna Sparrman and Bengt Sandin's (2012) concept of "situating child consumption", meaning that aspects of child consumption are 
situated and enacted in numerous different practices that for example create identities and social positions. Likewise we consider children's work to be situated and enacted in consumer culture. Thereby children's sales work can be scrutinized, not only by investigating what children themselves do, but also through texts and images that situate children in the arena of work. The study concentrates on mediated notions and values, recognizing that it is important to examine visual representations of children in order to understand societal notions of children and childhood, and hereby facilitating understandings for the conditions for contemporary childhood (Prout, 2005; Holland, 2004; Higonnet, 1998).

A critical visual methodology, where focus is on cultural significance, representations and power relations produced by the combination of images and text, is used to analyse the material (Rose, 2007; Sjöberg, 2013; O’Donnell, 2004). The analysis is executed by identifying recurrent themes in and between websites and then making detailed analysis on visual constructions concerning notions of children's work and the working child. Further discussed are the representations of 1.) The sales work process, 2.) Children's work tasks, 3.) The role of adults, 4.) The positioning of children as schoolchildren and 5.) The school trip.

A child perspective, that puts the focus on children and on effects for children's lives, is applied as an analytical tool (Halldén, 2003). Additionally a typology of metaphors for different kinds of free labour, or unpaid work, has been used. The typology, developed by Fast, Örnebring and Karlsson (2016) does not mention children. Still, its various positioning of nonemployed workers clarifies different positions of children in the website material.

\section{Material}

The four company websites were viewed online, saved, and analysed in spring 2015, and further complemented during 2016. They were found through a Google search using the Swedish term "sälja till skolresa", which closely translated into English equates to "sell for school trip". From 
eighty-two unique hits, four renowned Swedish companies, each ranking in the top eight for net sales in this branch in 2009 (Tonström 2010), were chosen. ${ }^{i}$ These are Delikatesskungen, offering sales of salami; Kakservice, offering sales of biscuits; Newbody, offering sportswear sales; and Tulpankungen, offering sales of seasonal flowers. ${ }^{\text {ii }}$ All these companies offer similar conditions for sales work, arranged so that the children, with the aid of catalogues, solicit orders from people in their close geographical and relational surroundings. Thereafter a collective order from the class is submitted. After delivery of goods from the company in question children distribute and collect money from the customers. Once the company has been paid its due the remaining pre-agreed percentage is available for the school class to spend on the school trip.

The websites promote the respective company to schoolchildren and associated adults searching for work for school classes to perform. The websites are intended to appeal to and convince viewers of both the company itself and their products' excellence. They are multiple page websites with a similar structure, containing a lot of information in text, images and video clips. Central parts are "How does it work?"-sections that describe terms and arrangements for sales work, and "References"-sections that include testimonial narratives in interviews and quotes from previous classes that are said to have had a successful partnership with the company. Together these two parts are vital in the companies' arguments of how and why schoolchildren should work.

The forthcoming analysis is structured in relation to how the websites present 1.) The sales work process, 2.) Children's work tasks, 3.) The role of adults, 4.) The positioning of children as schoolchildren and 5.) The school trip. 


\section{Analysis}

\section{The sales work process}

The companies address the website viewer as a member of a group of peers, talking to "you" and "your class". The companies are so specialized towards groups that it is impossible to enter into partnership as an individual work prospect. The conditions thus require a school class, or organised extra-curricular activity club, for children to be able to conduct sales work.

The websites inform the child viewer that to initiate working the school class should first decide where they want to go on their school trip and estimate how much money they will require. They are then able to use a calculating tool on the websites, showing how much they must sell to reach their set financial goal. The payment to the school class is entirely dependent on the number of sales they make. The next step is to contact the company, who subsequently deliver sales packages with catalogues, and in some cases product samples. Then the sales can begin. Kakservice enhances their written instructions of the sales process with a three-piece set of drawn cartoons. The first cartoon shows two children with smiling faces taking orders at a lady's door. In the next sequence other smiling children are speedily running with packages for delivery. Lastly, a third pair of children is adding to a stack of money supervised by a content looking male adult. What the cartoon illustrates is a work process indicated to be fun, quick, controlled and very lucrative. "References"-sections appear to give voice to real people's experiences. Here children, teachers and parents articulate how sales work undertaken by children represents a form of a fun leisure time activity whilst also providing a good financial profit in minimal time. Even though some children testify they were at first nervous to knock on unknown people's doors to try to find customers, in the end it is not portrayed as a trying task. It is said to be much easier than expected to sell the products and to reach set goals. Both Delikatesskungen's salami and Newbody's sportswear are testified to almost "sell themselves" 
as customers appreciate these products from previous school classes' sales campaigns. The overall communication is that the sales work equates to fast and easy money.

\section{Children's work tasks}

The companies emphasize that everyone in a selling school class must be dedicated to contributing towards the optimal sell and earn result, and that it is important to encourage one another. As such, children are positioned as active unified team players helping the group to attain its goal, positioning the individual more or less as an unselfish volunteer working to reach an altruistic goal in favour of others (Fast et al. 2016). Yet if the work leads to attainment of the set financial goal the individual will eventually participate in the school trip as a reward. In these circumstances the child worker is rather positioned as a hobbyist volunteer given affective payoff and being "paid in fun" (Fast et al. 2016).

The individual child's work task is, in practical terms, to find potential customers in their social network, as well as scouring the neighbourhood and outside of local commercial establishments, such as supermarkets and pizzerias, for sales opportunities. For a group of 25 pupils the companies suggest sales of 200 salamis, 450 boxes of biscuits, 378 sportswear items or 154 packages of flowers (providing the class total earnings ranging from 856 to 2218 euros). This means every child must set an individual goal of selling eight salamis, 18 boxes of biscuits, 17 sportswear items or 15 flower packages. These given examples by the companies set standards for how much the individual is expected to sell. With running totals, bonus systems for sales, and expectations of the final profit it will be clear to all in the class how well each child succeeds. In practice this puts social pressure on the individual and might create strains within the group, risking pitting children against one another instead of unifying the class.

In a list titled "Your own sales list" Kakservice exemplifies how to reach a sales target of 18 boxes of biscuits: sell two boxes to mom and dad, one to grandmother, five to neighbours, 
three at mom's workplace, three at dad's workplace and four by knocking on doors. To enhance the sales further children are recommended to hand out information leaflets, put up posters and website banners, make notifications on Facebook and text friends and distant relatives to inform of their sales campaign. Advice from a class of sixth graders on Tulpankungen's website is to "Start selling immediately", "Make product recommendations", "Offer sales to anyone you meet" and "Smile all the time". When the selling period is over and the delivery from the company has arrived the goods should be allocated amongst the class for further delivery and payment. The sixth graders on Tulpankungen's website then recommend e-mailing or texting the customers in advance to make sure they are prepared when the salesperson seeks them out for delivery and payment.

In Delikatesskungen's instructional video children are indeed briefly seen performing many of the above assignments, but besides that there is a remarkable lack of images showing children working, or even children in work-like situations. One of few photographs alluding to the work involved is on Kakservice's website, hidden from initial viewing unless a specific "Reference"-section is viewed and an extra group of images opened. The photo, typical for this kind, shows four content looking children walking in a sunny open area. One of the boys pulls a trolley in which one can glimpse boxes of various shapes. The image can be interpreted as an illustration of what it looks like when ordered biscuits are to be delivered. But since ease and contentment, rather than working aspects, are highlighted it can equally be interpreted as that of four friends in a non-working leisure situation. The lack of work-situated photos, in favour of leisure images, makes it look as if children do not really have to work to get the work done. This minimizes the impression of work effort demanded. 


\section{The role of adults}

\section{The contact person}

In descriptions of decision-making regarding beginning work-for-funding and setting goals children are portrayed as competent and more or less actively involved. In "References"sections however it is parents or teachers, not children who are said to have taken initiative to engage the class in the sales work in cooperation with the particular company. Besides leading children to start working, none of the stages of the work process can be conducted without at least one adult. For even though the companies' websites address their communication directly to schoolchildren, being able to progress to a partnership leaves these same children reliant upon an adult "contact person" to enter a legal agreement with the company, including agreeing to full personal financial liability until the process' end. The contact person, who explicitly or implicitly overlaps with a teacher or parent, has to be a minimum of 18 or 20 years of age, depending on the company.

As per the financial agreement the contact person is responsible for collecting money from the children after deliveries, and making sure the partner company is paid within the allotted time. He or she should distribute sales guides and catalogues, organise the sales, and administrate the collective order. "Reference"-sections clearly state that the contact person's role is substantial, indicated as functioning as a pep squad encouraging the class to reach their set goals and/or to sell more, and as a liaison between the company, the school class, teachers and parents. The contact person is described as being "at the heart of things" (Delikatesskungen), the one having "full control" (Kakservice) and the person "managing the sales process" (Newbody). He or she is thus positioned as the project leader of the work, making the schoolchildren follow an adult's lead. Delikatesskungen's website even refers to a contact person and his "mentees" (Delikatesskungen). In contrast to a more frequent position as active 
and independent, children are, in relation to the contact person, positioned as subordinates. In parallel to other work forces their role is similar to consultants or temporary agency workers.

\section{Parents}

Besides child workers and the contact person, teachers and parents are also present on the websites. Teachers are the most visually represented adults and highlighted in "References" as very supportive, discussing funding ideas in the class and during parent meetings, administrating practical details of the work, and in the school trip coming to fruition. According to implications for children however, descriptions of parents are the most interesting. As mentioned above parents are, in comparison with family friends and relatives, suggested as potential customers. The companies encourage children to transform their private contacts into economic relations, and to use emotional relations for economic benefits. In the case of parents, journalistic inquiries witness children's sales work for school trips as leading to a high level of family purchases. This means that although the law states that parents may only occasionally and voluntarily contribute to school associated costs with nominal amounts of money (SFS 2010:800,10§10,11), parents contribute economically to the school trip after all (Gussarsson, 2015).

Additionally parents are described as involved in the sales process. Delikatesskungen, Kakservice, and Tulpankungen explicitly state that "the family", not the child or school class, are to decide how many products they can be expected to sell. Parents are also mentioned as assisting their child with administering sales and delivery. Children are furthermore instructed to ask parents to sell products at their place of employment, which is stated as a previously successful tactic to increase sales and thus profit. This means parents are expected to share their child's work tasks, which ties in to previous research findings of children in part-time employment being assisted by their parents. Parents drive the child to and from the workplace, 
and occasionally they even conduct work tasks for the child (Gasson et al. 2015). By positioning parents as integrally involved they are represented as performing free labour as a carer in the emotional sphere. Involvement is undertaken for the sake of the own child, as well as a volunteer working altruistically for the sake of the school class as a whole (see Fast et al. 2016). Parents' work is an extension of the main worker - the child's work efforts. In this regard parents are positioned as working for the child. In a contradictory way this constructs the child both as subordinate to and as in charge of adults.

\section{The positioning of children as schoolchildren}

Classes' headquarters for the sales process, of plans made and sales tallied, are visualized as being the classroom. However, it is rarely the planning and discussion of the sales work that occurs in the classroom images. Many instead show children engaged in traditional schoolwork and being helped by a teacher. Together with arranged class photos this visualizes and stresses children as first and foremost being schoolchildren. The addressed children are indeed schoolchildren, yet the positioning of them as specifically schoolchildren has the effect of downplaying their role as workers.

The schoolchild role is enhanced by texts highlighting learning as an integral part of the sales work process. It is said that children's sales work affords possibilities to include practical application of school subjects, usually taught and learnt through pages of an exercise book. Mathematics, through finance and economy, is for instance said to be brought to life through calculating and following sales and profit margins. Another example given regarding learning competencies are sales-techniques, including how to conduct oneself when approaching potential customers in sales situations. Companies are explicit in that the optimal way to learn is by doing; however, that the doing in this case is akin to working is disregarded in favour of promoting learning. Since no children in "Reference"-sections mention educational benefits 
this aspect does not appear to be a vital argument for children. Rather it seems to be presented to persuade adults of the benefits of sales work.

The strong emphasis of the learning schoolchild communicates the sales work as a means for learning and as such as a benefit for the future. The working child is thus less positioned as appreciated for the work conducted in the present, than as an "apprentice" rewarded with experience (see Fast et al. 2016).

\section{The school trip}

Similar to what Engwall et al. (2008) note, all companies highlight an aim to "help" children to realize their dreams. The websites state that selling and earning leads children to adventure, entertainment and memories that will last a lifetime, with reference to the school trip. Other classes that have already reached their goals and experienced their dream school trip are constantly present in image and text, symbolising the fun experiences expected once the sales process is complete.

Environments ranging from Sweden's largest cities to its wilderness are presented as viable destinations, and historical sites and science workshops are given as examples of combining educational visits with non-curriculum related visits. Written catchy sentences, such as "The school trip was a success for Ängås-school” (Delikatesskungen), "Liseberg amusement park dream becomes reality" (Kakservice), and "Count the money and plan the adventure" (Tulpankungen) relay happy experiences supporting the message that sales work leads to unforgettable and fun activity days. This message is enhanced in photographs showing children with big smiles in non-everyday environments and situations: on camping excursions, enjoying water sport activities, having fun at theme parks and visiting cities.

A majority of all photos and videos used, including those showing school environments, depict close physical proximity, e.g. children leaning shoulder to shoulder or resting an arm on 
each other. Whether the images show large assembled groups or a few children, these images visually construct a close and trusting relationship. As a result togetherness and overall camaraderie seems promoted as an end goal, just as much as the school trip itself. The reward for work thus comes along with the work process and culminates in the school trip. The children then appear as "hobbyist" workers only ever expecting affective payment, being "paid in fun" (Fast et al. 2016).

\section{Discussion}

By scrutinizing websites from Swedish companies offering short-term partnerships with school classes this study has given insights into publicly expressed notions of children's work in prosperous countries where children do not have to work for survival, but yet do work. The aim has been to explore how companies specializing in a schoolchild work force, specifically the companies Delikatesskungen, Kakservice, Newbody and Tulpankungen, visually position children's work and the working child.

What the study reveals is the companies' reluctance to show and position children as workers. There is an almost total visual absence of children performing work and instead focus is placed on joy. Thereby the companies seem unwilling to show the full implications of entering a partnership with them. The effect is that the sales work offered seems undemanding, done without inner or outer hardships. Descriptions regarding how to improve sales however indicates that there is much more to the work than just selling and earning. Putting up posters, texting, e-mailing and other efforts are mentioned as valuable advice to enhance sales, rather than being part of the primary work process. Such communication of endeavours as voluntary downplays the necessary engagement, again promoting the work requirement from the corporate partner as undemanding, or at least as undemanding as the class (and associated adults) decide. Constantly the joy of achieving something together is enhanced, positioning the 
work as partly self-sacrificing. Persistent descriptions of the sales work in terms of teamwork obscure the more or less demanding individual effort. Potential individual struggles and difficult working aspects connected to real life sales situations, for example miscalculations and impolite customers, are never mentioned. Neither are the risks of failing to reach sales targets or being exposed to negative group-dynamics. Problems like these are muted as if they are unlikely to occur, and therefore left for involved parties to foresee and react upon without companies providing any preparation. This reveals a logic equivalent to the websites' purpose of promotion. It might be more successful to recruit school classes if the work appears as easy, well paid and without friction. At the same time, children are constructed as unable to handle facts of working life. Following on from this is a notion of children as unwilling to engage in work and in need of persuasion to conduct any work related tasks.

Throughout the websites children are positioned as capable, yet, they cannot accomplish sales work without an adult contact person in charge. By delegating responsibility to the contact person the companies disclaim themselves from any legal obligations as employers, which further contextualizes the sales work as a profitable hobby, and not as part of the formal economic sphere and labour market. In so doing children's work is positioned as not being real work. Further, the fact that parents, upon closer inspection, are given a significant role minimizes the notion of children as being workers independently managing their own work tasks. One can even question if children actually have to work, or whether the sales work can in practice be completely handed over to parents.

The strong notion of the child as a schoolchild removes focus from the individual's workeffort and conveys the sales work as controlled and safe. Being embedded in a school context, but to be conducted during spare time, the sales work is given a status as a form of homework. It further positions the child as learning skills for the future, equating to a standard notion of 
children as "becomings" (Lee, 2001), a notion much less controversial than the working child; a notion with possible negative connotations to poor child labourers.

Memorable experiences, fun and closeness are promoted as significant outcomes throughout the sales process and primarily concern the school trip. Money earned is thus simply a means to attaining a good time. This positions children's sales work as something providing a silver lining to a normally safe and prosperous everyday life. It differentiates the schoolchild workers from children who must work for survival, or in other words children engaged in child labour. All in all what the companies do is position children's work as what one could label "play work" and "work learning", actively creating a distance to a form of children's work that most people find unjust and repulsive.

The described work process is not of real work but of fun, schoolwork and leisure, exemplified by and culminating in the school trip. The work process is tilted towards a hobby situation within a school and family context, with an outcome of fun and learning. This construct conforms to the Swedish employment law (SFS 1977:1160) and it is further connected to a carefree happy childhood ideal. It is an ideal that the companies suggest comprises of close relations to peers leading to shared happy experiences and togetherness, highly supportive parents and engaged teachers. The happy childhood ideal is in great contrast to notions of child labour, aligning with the existing non-working child perception in Sweden. It promotes a notion of the non-working childhood, in effect strengthening the perception that children in Sweden do not work (Samuelsson 2008). Paradoxically the companies try to recruit child workers while at the same time dissociating themselves from working children. 


\section{References}

Aretun, ̊̊. (2007). Barns "växa vilt" och vuxnas vilja att forma: formell och informell socialisation i en muslimsk skola. Diss. Linköping: Linköpings universitet.

Bourdillon., M, Levison D., Myers W., White B. (2010). Rights and wrongs of children's work. New Brunswick, N.J.: Rutgers University Press.

Cross, G. (2004). Wondrous Innocence, Print advertising and the origins of permissive child rearing in the US. Journal of Consumer Culture, 4, 183-201. Doi $10.1177 / 1469540504043681$.

Delikatesskungen AB Website. https://www.delikatesskungen.se [1 september 2016].

Engwall, K. \& Sjöberg, M. \& Söderlind, I. (2008). Var och med vad arbetar barn?. In Söderlind, I. \& Engwall, K. (Eds.), Barndom och arbete (pp. 107-150). Umeå: Boréa.

Engwall, K. \& Söderlind I. (2009). Child Work and Child Labor in Sweden Today. In Hindman H.D. (Eds.), The world of child labor: an historical and regional survey (pp. 600-601). Armonk, N.Y.: M.E. Sharpe.

Eydal, G., Rafnsdóttir, G. \& Einarsdóttir, M. (2009). Working Children in Iceland: Policy and the labour market. Barn, 3-4, 187-203.

Fast, K., Örnebring, H. \& Karlsson, M. (2016). Metaphors of free labor: a typology of unpaid work in the media sector. Media Culture Society, 38, 963-978. doi: 10.1177/0163443716635861.

Gasson, R., Calder, J., Diorio, J., Smith, A. \& Stigter, J. (2015). Young people's employment: Protection or participation? Childhood, 22, 154-170. doi:10.1177/0907568214524456.

Gennaro, S. (2010). Making Kids Sexy: Sexualized Youth, Adult Anxieties, and Abercrombie \& Fitch. Red feather Journal, 1, 56-72.

Gussarsson, E. (2015 september 1). Dags för skolresa: pepp eller pina?. Mama, pp. 140-142.

Halldén, G. (2003). Barnperspektiv som ideologiskt eller metodologiskt begrepp. Pedagogisk Forskning $i$ Sverige, 8, 12-23.

Higonnet, A. (1998). Pictures of innocence: the history and crisis of ideal childhood. London: Thames \& Hudson.

Hobbs, S., Stack, N., McKechnie, J. \& Smillie, L. (2007). Talking about Work: School Students' Views on their Paid Employment. Children \& Society, 21, 123-135. doi:10.1111/j.1099-0860.2006.00030.x.

Holland, P. (2004). Picturing childhood: the myth of the child in popular imagery. London: I. B. Tauris.

Howieson, C., McKechnie, J. \& Semple, S. (2012). Working pupils: challenges and potential. Journal of Education and Work, 25, 423-442. doi: 10.1080/13639080.2012.708723.

Kakservice AB Website. http://www.kakservice.se [1 september 2016].

Kaziaj, E. (2016). "The adult gaze": exploring the representation of children in television news in Albania. Journal of Children and Media, 10, 426-442.

Kverndokk, K. (2007). Pilegrim, turist og elev: norske skoleturer til dфds- og konsentrationsleirer. Diss. Linköping: Linköpings universitet.

Larsen, S. \& Jenssen, D. (2004). The school trip: Travelling with, not to or from. Scandinavian Journal of Hospitality and Tourism, 4, 43-57. doi: 10.1080/15022250410006273

Lee, N. (2001). Childhood and society: growing up in an age of uncertainty. Maidenhead: Open University.

Leonard, M. (2003). Children's attitudes to parents', teachers' and employers' perceptions of term-time employment. Children \& Society, 17, 349-360. doi: 10.1002/CHI.760. 
Lindahl, U. (2016 june 1). Miljonvinst på barn som säljer för laget, Dagens ETC, pp. 6-7.

Markovich, D. (2016). Ethnicity vs. national culture in one nationalized educational site: the case of the annual school trip. Critical Studies in Education, 57, 238-253. doi: 10.1080/17508487.2015.1013562.

McKechnie, J., Hobbs, S., Simpson, A., Anderson, S., Howieson, C. \& Semple, S. (2010). School students' part-time work: Understanding what they do. Journal of Education and Work, 23, 161-175. doi: 10.1080/13639080903565665.

Mizen, P. (2005). A little 'light work'? Children's images of their labour, Visual Studies, 20, 124-139. Doi:10.1080/14725860500244001.

Newbody AB Website. http://www.newbody.se [1 september 2016].

Nöjd, M. (2008). Skolbarn ger klirr i kassan. Råd \& Rön, 3, 33-35.

O’Donnell, V. (2004). Cultural Studies Theory. In Smith, K.L., Moriarty, S., Barbatsis, G. \& Kenney, K. (Eds). Handbook of Visual Communication: Theory, Methods, and Media. (pp. 521-538). Mahwah, N.J.: Lawrence Erlbaum.

Prout, A. \& James, A. (1997). A New Paradigm for the Sociology of Childhood? Provenance, Promise and Problems. In James, A. \& Prout, A. (eds). Constructing and reconstructing childhood: contemporary issues in the sociological study of childhood (pp. 7-32). London: Falmer.

Prout, A. (2005). The future of childhood: towards the interdisciplinary study of children. London: Routledge Falmer.

Rantatalo, P. (2002). Den resande eleven: folkskolans skolreserörelse 1890-1940. Diss. Umeå: Umeå Universitet.

Riggs, D., King, D., Delfabbro P. \& Augoustinos, M. (2009). Children Out of Place, Journal of Children and Media, 3, 234-248. doi:10.1080/17482790902999918.

Rose, G. (2007). Visual methodologies: an introduction to the interpretation of visual materials. 2. ed. London: Sage.

Samuelsson, T. (2008). Children's Work in Sweden - A part of childhood, a path to adulthood. Diss. Linköping: Linköpings universitet.

SFS 1977:1160, Arbetsmiljölagen.

SFS 2010:800, Skollagen.

Sjöberg, J. (2013). I marknadens öga: barn och visuell konsumtion. Diss. Linköping: Linköpings universitet.

Sparrman, A. \& Sandin, B. (2012). Situated child consumption: An introduction. In Sparrman, A., Sandin, B. \& Sjöberg, J. (Eds.), Situating child consumption: Rethinking values and notions of children, childhood and consumption (pp. 9-31). Lund: Nordic Academic Press.

Tonström, E. (2010 November 27). Barnens arbete drar in miljoner. Svenska Dagbladet. Näringsliv, p. 4.

Tulpankungen AB Website. http://www.tulpankungen.se [1 september 2016].

Wells, K. (2008). Child saving or child rights, Journal of Children and Media, 2, 235-250. 
${ }^{\mathrm{i}}$ Eliminated from consideration were company websites lacking information regarding target ages, information on the working process, or having a dominant focus on non-school groups, such as sports clubs.

ii Parts of the websites target groups other than school classes and some offer other services. This analysis focuses only on parts of the websites giving specific work-for funding information, supported with relevant information regarding the school year/age of the targeted children. 